\title{
EFFECTS OF CONTINUOUS TRAINING AND DEVELOPMENT ON RAPID RESPONSE UNIT FOR IMPROVING TIME INTERVENTION
}

\author{
Sonya Pebriani ${ }^{1}$, Sugeng Riyanto ${ }^{2}$, Pupung Purnamasari ${ }^{3}$, Allessandro Setyo Anggito \\ Utomo $^{4}$, Mikael Januardi Ginting ${ }^{5}$, Anodho Wijanarko ${ }^{6}$ \\ ${ }^{1,2.3}$ Department of Management, Faculty of Economics and Management, STIE Pertiwi, Bekasi, \\ West Java, 17112 Indonesia \\ ${ }^{4}$ Department of Mechanical Engineering, Faculty of Engineering, Universitas Indonesia, West \\ Java, 16424 Indonesia. \\ ${ }^{5}$ Marine Science Postgraduate Program, Faculty of Mathematics and Natural Science, \\ Universitas Indonesia, West Java, 16424, Indonesia. \\ 6 Department of Chemical Engineering, Faculty of Engineering, Universitas Indonesia, West Java, \\ 16424 Indonesia. \\ sonya.pebriani@pertiwi.ac.id ${ }^{1}$; Sugeng.riyanto@pertiwi.ac.id ${ }^{2}$; \\ pupung.purnamasari@pertiwi.ac.id ${ }^{3}$; allessandro.setyo@gmail.com ${ }^{4}$; mikaelginting@ui.ac.id ${ }^{5}$; \\ anondho.wijanarko@ui.ac.id ${ }^{6}$
}

\begin{abstract}
The research conduct a case study on the rapid response unit through a quantitative approach regarding the effect of continuous training and development for in resolving emergencies and developing rapid response system. The Rapid Response Unit (RRU) is a unit that helps avoid the risk of adverse events that threaten the safety of community interaction in the area in the campus forest area. However, the unit's existence is not enough to only present physiques with the available time to help secure and control various of events in the campus forest area. An increase in hard and soft skills is needed to maintain quality of rapid response unit human resource. The study results indicate an impact in resolving incidents based on the time spent of intervention in the crucial level of the incident, the level of familiarity of events for the field officers, and the adequacy of training provided.
\end{abstract}

\section{Keywords: Rapid Response; Human Resource; Training; Development; Impact}

\begin{abstract}
ABSTRAK
Penelitian ini melakukan studi kasus pada unit respon cepat melalui pendekatan kuantitatif mengenai pengaruh pelatihan dan pengembangan berkelanjutan untuk mengatasi keadaan darurat dan mengembangkan sistem respon cepat. Unit Respon Cepat (RRU) merupakan unit yang membantu menghindari risiko kejadian buruk yang mengancam keselamatan interaksi masyarakat di kawasan dalam kawasan hutan kampus. Namun keberadaan unit tersebut tidak cukup hanya menghadirkan petugas waktu tertentu yang tersedia untuk membantu mengamankan dan mengontrol berbagai peristiwa di kawasan hutan kampus. Peningkatan hard skill dan soft skill diperlukan untuk menjaga kualitas SDM unit respon cepat. Hasil studi menunjukkan dampak penyelesaian insiden berdasarkan waktu yang dihabiskan untuk intervensi insiden, tingkat keakraban peristiwa bagi petugas lapangan, dan kecukupan pelatihan yang diberikan.
\end{abstract}

Kata Kunci: Reaksi Cepat; Sumber Daya Manusia; Pelatihan; Perkembangan; Dampak

\section{INTRODUCTION}

A rapid response unit is a unit that moves to prevent possible hazards, respond to hazards that occur based on incidents occurring in an area, and evaluate incidents so it cannot be repeated or can be avoided. Rapid reaction units respond to several categories of accidents or incidents. Based on Jones.et al [1], the rapid reaction unit has a function to prevent disaster victims' health deterioration. The research proposed that victims will 
experience a reduction in their likelihood of living due to an accident. The deterioration occurs within several hours after they experience an accident or sickness so that treatment is needed as soon as possible.

Furthermore, handling requires a method to identify accidents that have occurred. The rapid response team was designed to identify and mitigate events discussed an excellent handling system for the rapid reaction team to implement [2-4]. The system is stated in 3 forms: Identifying the hazards that occur, handling on-site, and evacuation. Hilman et al. [5] also stated the rapid response team's advantage.

Out of 1000 patients identified as having a heart attack, only less than ten had to undergo intensive treatment in the hospital due to the rapid reaction team's intervention in carrying out treatment. The same study conducted by Chen et al. [6] showed that rapid response units could reduce $23 \%$ mortality from cardiac events. Jones et al. [7] also discussed the prolonged effect of the fast reaction unit. The effect is seen that the rapid reaction team brings a high safety culture to its area. This culture is caused by the initial identification of the dangers and risks in the operational area. So that culture creates an environment that is attentive to safety. However, this effect must be prolonged training and education to enrich the community around the operational area, which is the rapid reaction team's function. Education can only be given when continuous training is carried out for the team so that the team is considered to have the capability to teach hazard and risk rescue techniques and improve the performance of interventions carried out by non-rapid reaction units. Bristow et al. [8] responded to this by stating that continuous training can improve future worker performance.

Pamar et al. [9] also prioritize evaluating performance carried out before and after implementing development programs for employees who work. Training and development programs can produce internal developments within the training participants such as high morality, eliminating risks in doing work, increasing managerial skills in the team, and improving workers' quality [10]. In this study, the authors wanted to show an increase in quality in the intervention based on the speed of intervention, reduction of predictable accidental cases, and improvement in response time for single accidents, accidents with multiple victims, and chronic. It showed whether training and team development had a positive impact on handling incidents.

\section{RESEARCH METHODS}

The research was reviewed based on data obtained with the University of Indonesia's Rapid Reaction Unit's approval. The assessment of the fast reaction unit's performance is based on the number of cases that occur. These cases include single accidents, multiple casualty accidents, and illness complaints by visitors to the University of Indonesia campus forest area. Data is taken based on the period 2017 to 2020 for 40 months the Rapid Reaction Unit operates. The formation of the University of Indonesia's Rapid Response Unit team was formed in 2015.

However, from 2015 to 2016, there was no special training based on hazard categories and the campus forest area's risk of events. The data obtained by the author is from January 1, 2017, to April 15, 2020. The recorded single and multiple accidents and illness complaints are collected and categorized based on the calling criteria, Brilli et al. [11] for the University of Indonesia's rapid reaction unit, incident demographics, source of disease, list of complaints, date of the incident, and handling time starting from activation of the rapid response unit or complaints received. Activation of the Rapid Response Unit at the University of Indonesia is based on several criteria in table 1. 
Table 1. Activation Criteria for Rapid Response Unit Activation Criteria for the RRU

- $\quad$ Require more exceeding effort to do breathing.

- The occurrence of saturation of less than $90 \%$ despite being given oxygen.

- Cyanosis

- Lack of Consciousness of the victim

- There are concerns regarding the victim by people nearby

\section{Pre-intervention}

Before discussing the research results, it is necessary to know that discovering the Rapid Response Team of the University of Indonesia, training, and developing the team skills were carried out between 2016 and 2020. The training was conducted for Rapid Response Unit officers based on the possible dangers in the campus environment. All officers conduct training, even though the University of Indonesia Rapid Response Team (RRT) has two different functions, namely RRT 699 and RRT 911. RRT 699 functions as a team responsible for evacuating medical first aid, and 911 is tasked with eliminating problems caused by external factors such as towing, logging, water rescue, and firefighting.

Table 2 shows the training process for rapid response team officers for the past five years. The training aimed to be carried out by the entire team. Therefore, all Rapid Response Unit personnel could carry out RRT 699 and 911 assignment.

Table 2. Training and Development Timeline

\begin{tabular}{ll}
\hline \multicolumn{2}{c}{ Training and Development Timeline } \\
\hline Venomous Snake Intervention & January 2016 \\
Rescue and Ambulance Basic Life Support & March 2016 \\
Basic Rope Skill & March 2017 \\
Vehicle Towing Training and Simulation & February 2018 \\
Basic Vehicle Repair & February 2018 \\
Fire Fighting Training & August 2019 \\
Water Rescue Training & August 2019 \\
\hline
\end{tabular}

Based on the training conducted to support the validation of time and process in mitigating a problem that appears in the campus environment. The intervention system is based on measuring the probability and severity of the problems faced, as shown in table 3. Personnel training and development results in personnel thinking patterns to go through 4 processes, according to Hollnagel et al. [12-13] namely anticipating events that may occur, monitoring and responding to hazards, and evaluating performance systematically and structured manner. 
PUBLIK: Jurnal Manajemen Sumber Daya Manusia, Adminsitrasi dan Pelayanan Publik Sekolah Tinggi Ilmu Administrasi Bina Taruna Gorontalo Volume VIII Nomor 1, 2021

Table 3

Probability \& Severity level

\begin{tabular}{|c|c|c|c|c|}
\hline \multicolumn{2}{|r|}{ Accidental } & \multicolumn{3}{|c|}{ Chronic } \\
\hline Acuteness & Likelihood & Acuteness & Exposure & Level \\
\hline Nontreatment & Never occurred & $\begin{array}{l}\text { Short term } \\
\text { defect }\end{array}$ & $\begin{array}{l}\text { Unprecedented: } 1-2 \text { hour } \\
\text { per year }\end{array}$ & 0 \\
\hline $\begin{array}{l}\text { Treatment } \\
\text { without low } \\
\text { control }\end{array}$ & Never occurred but possible & Chronic defect & $\begin{array}{l}\text { Occasional: 1-2 hour per } \\
\text { month }\end{array}$ & 1 \\
\hline $\begin{array}{l}\text { Treatment } \\
\text { with partial } \\
\text { control }\end{array}$ & $\begin{array}{l}\text { Occurred at least once every } \\
\text { two years }\end{array}$ & $\begin{array}{l}\text { Disable } \\
\text { Impairment }\end{array}$ & $\begin{array}{l}\text { Regular: 1-2 hour per } \\
\text { week }\end{array}$ & 2 \\
\hline $\begin{array}{l}\text { Fatal or no } \\
\text { control }\end{array}$ & Occurred at least once a year & $\begin{array}{l}\text { Fatal } \\
\text { impairment }\end{array}$ & Constant: $1-2$ hour a day & 3 \\
\hline
\end{tabular}

\section{Identification}

The identification process uses reference sources regarding the initial assessment for victims on a scale of 0 to 3 and based on three assessment components, namely, the victim's behavior at the time of question, respiratory state, and cardiovascular state [14]. These criteria are used because they have been clinically tested as a pediatric early warning score or PEWS process described in table 4.

Table 4. PEWS Scoring

\begin{tabular}{lllll}
\hline \multicolumn{1}{c}{ Components } & \multicolumn{1}{c}{$\mathbf{0}$} & \multicolumn{1}{c}{$\mathbf{1}$} & \multicolumn{1}{c}{$\mathbf{2}$} & \multicolumn{1}{c}{$\mathbf{3}$} \\
\hline Victim's Behavior & Proper & $\begin{array}{l}\text { Concern about } \\
\text { the pain }\end{array}$ & $\begin{array}{l}\text { Uncontrolled pain, } \\
\text { Difficult to } \\
\text { Communicate }\end{array}$ & $\begin{array}{l}\text { Unexplained } \\
\text { decrease in } \\
\text { consciousness }\end{array}$ \\
Respiratory Rate & $>30 / \mathrm{min}$ & $<7 / \mathrm{min}$ & $<6 / \mathrm{min}$ & Oxygen Needed \\
$\begin{array}{l}\text { Cardiovascular } \\
\text { State }\end{array}$ & $\begin{array}{l}\text { Normal Blood } \\
\text { pressure }\end{array}$ & $\begin{array}{l}\text { Pale, Capillary } \\
\text { refill }<3 \mathrm{sec} .\end{array}$ & $\begin{array}{l}\text { Grey, Capillary refill } \\
3 \text { sec to 4 sec. }\end{array}$ & $\begin{array}{l}\text { Capillary refill }>4 \\
\text { sec. }\end{array}$ \\
\hline
\end{tabular}

\section{Intervention}

The intervention process is carried out based on several stages; First, the officer receives a report on the events discussed above regarding the rapid response team's activation. Second, the officer checks the equipment and tools needed at the time of the intervention and then immediately goes to the scene. Third, at the location, the officer identified the identity and asked for a chronology of the events. The officer provides a nominal or rating scale for the identification results based on the existing activation components.

Based on the identification results, the officers provide help on the spot or carry out an evacuation. The bedside officer then recorded the time and wrote a report on the actions taken, and the time data registered originate from the before and after the intervention's completion. The procedure for first aid and medical evacuation can be seen in figure 1. 


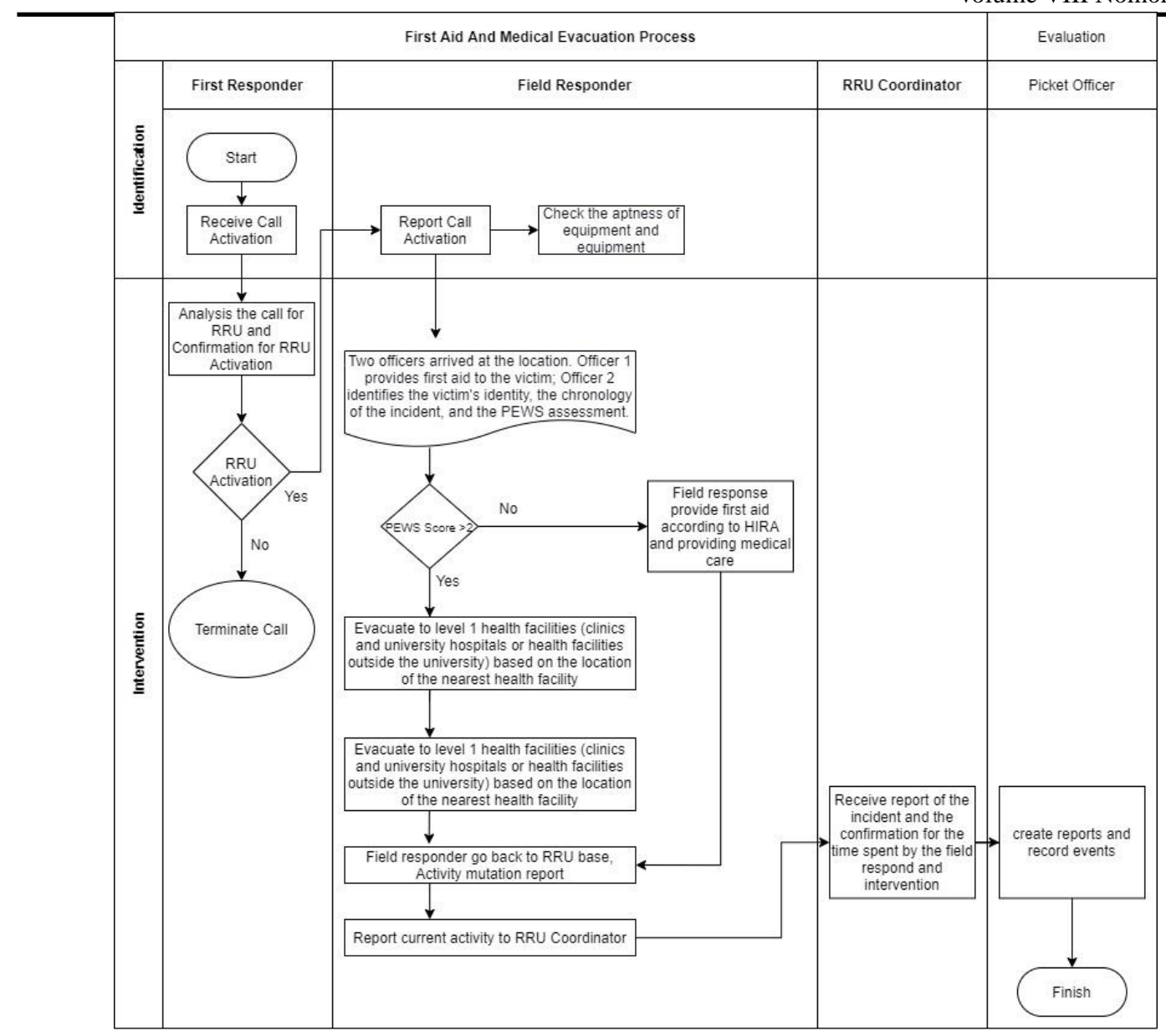

Figure 1. Rapid Response Unit System

\section{Proposed Study}

The investigation conducted in this study saw that the effect of training and development on rapid response unit officers had a different impact on the intervening systems that had been established from 2015 to 2020. In 2015, the formed system did not have any particularity in calculating the speed of intervention or any structural workflow. Examining the rapid response systems used in 2015-2016 is made based on proactive identification when an incident occurs. The rapid response system changed based on Gheorge et al. [15] was implemented from 2017 to 2020. It became a benchmark for the team to move in the following year based on the efficiency of system use, which will be discussed further in the result section.

\section{Results}

Based on the data obtained by the university's rapid response unit for services in the campus area of the University of Indonesia, Depok. Three things can be seen in figure 2 and figure 3. First, the crucial level of occurrence seen is based on the high level of the sinusoidal magnitude of the time it takes to deal with a problem influenced by the PEWS assessment and the severity level that is assessed at when activating the rapid response unit. In figure 2, regarding single traffic accidents, it can be seen that in March 2016, March 2018, and January 2020, there were events with high time fluctuations supported by a high PEWS rate and a high severity level reaching level 3. 

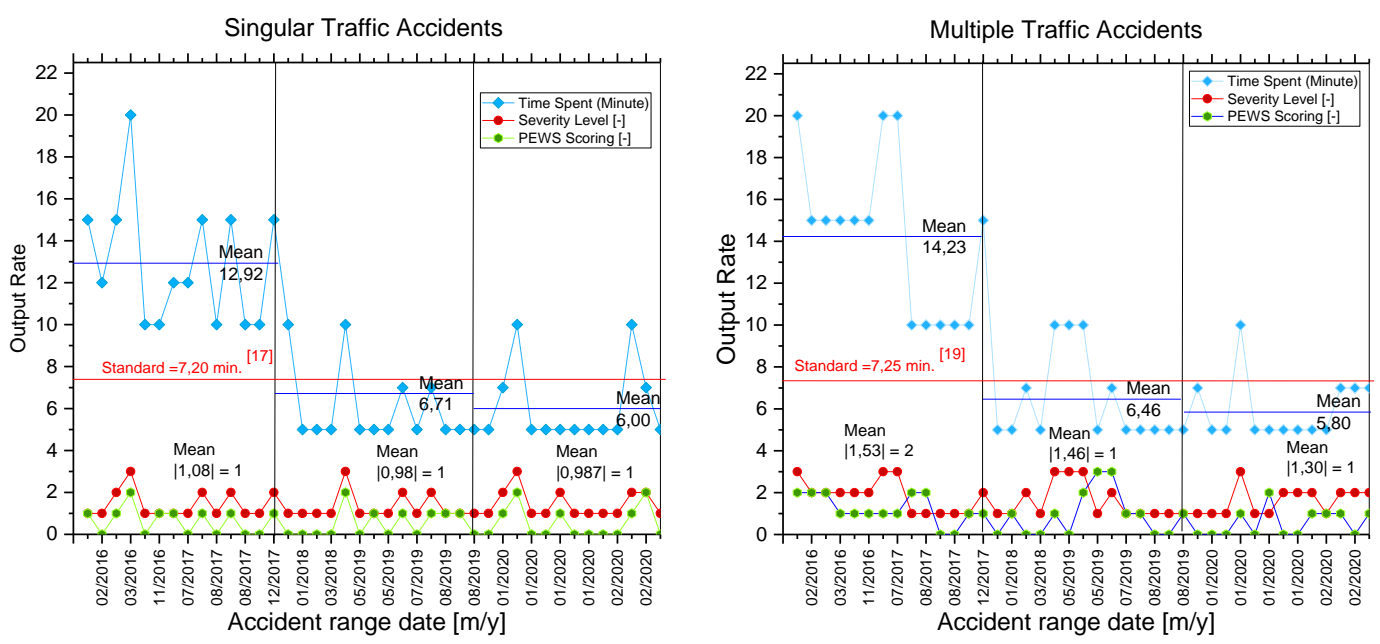

Figure 2. Singular and Multiple Traffic Accidents

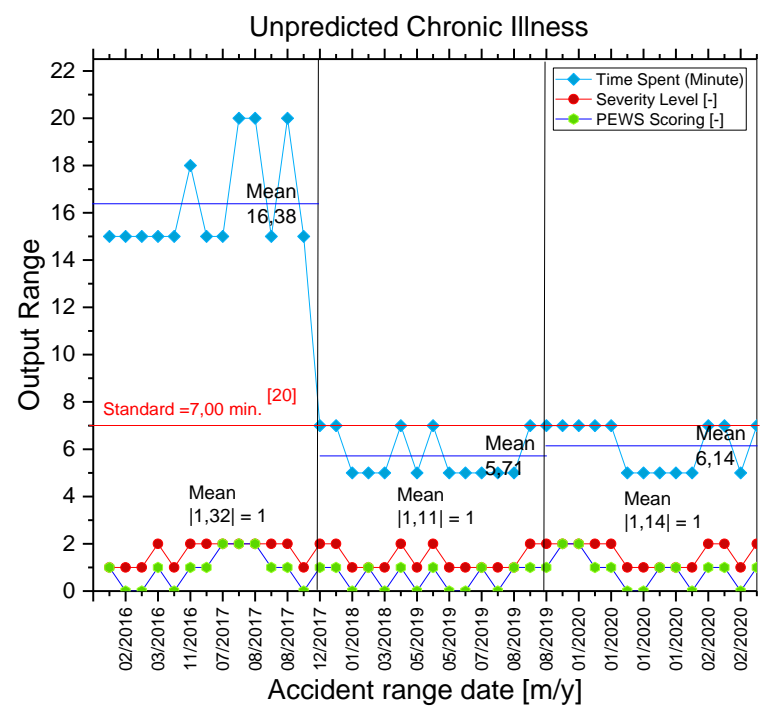

Figure 3. Unpredicted Chronic Illness

The change was due to accidents involving a level of damage at vehicles, and the level of injury suffered by victims is rated as high. The high level of austerity resulted in the time needed to evacuate the victims. The evacuation of the victim's property to the hospital took a long time, resulting in damaged vehicle towing. The same data can be seen on the multiple traffic accidents in November 2016, August 2017, March 2018 to May 2019, and January 2020, as well as data on unpredicted chronic pain of visitors and students in figure 3. Namely in the period July-August 2018, March 2018 to May 2019, and January 2020, which was caused by an unpredictable disease that brought the victim's position to a stage where the victim was unconscious or victim's difficulty in communicating the feelings and events experienced.

Thus, the data shows that an incident's severity causes the length of time for the unit to solve a problem. An event with high severity that takes longer to be resolved through two considerations is based on the victim's assessment of calling the rapid response unit based on the severity level. Next, the assessment of field officers is based on PEWS Scoring. Because the severity level experienced by the victim is not always coherent with the expert's assessment, this can be seen at the sinusoidal level on the different graphs 
between the severity level reported by the victim are higher than the PEWS Scoring assessment. This is because the victims usually rate higher in their situation based on their intuition. In contrast, PEWS is a rate by the biological condition of the victims by the rapid response personnel.

Second, in addition to the relationship between the factors that affect the visual fluctuations presented in Figures 2 and 3. Trends in sinusoidal values show a relationship between PEWS Scoring and severity levels with time service (time spent) during five years of operation of the university unit's rapid response to the campus environment. The differences can be seen from the rapid response unit's performance in the Q1, Q2, and Q3 timescales for three different events. In Q1 in Figures 2 and 3, respectively, service time has 12.92 minutes for single traffic accidents, 14.23 minutes for multiple traffic accidents, and 16.38 minutes for unpredictable illnesses of visitors and students.

In contrast, the rapid response unit operation in Q3 in Figures 2 and 3, respectively, is 6.00 minutes for a single traffic accident, 5.80 minutes for multiple traffic accidents, and 6.14 minutes for unpredictable illnesses. This significant decrease occurred during the 5-year process. Rapid response units have experienced familiarity variations with events that occur in the campus environment. The more service time the rapid response unit relief, the more evaluation provided from the unit works, as evidenced by the reduced mitigation time per event over five years. The evaluation process occurs in assessing the activation and assessment of PEWS supporting performance, following in stimulating the time of service provided in dealing with life-threatening cases with procedures determined by the International Federation of Red Cross [16].

\section{Discussion}

In this study, the authors want to discuss three main things: The incident's critical level. Second, the level of familiarity with field officers to carry out mitigation or handling actions. Lastly, the adequacy of supporting training such as first care training (Basic Life Support and First Aid Training), car towing training, car repair, firefighting, and water rescue. The time of the incident is divided into three periods from 2018 to 2017 (Q1), 2017 to 2019 (Q2), and 2019 to 2020 (Q3). This period's selection was determined as this range because continuous training was carried out in early 2016 to the end of 2019 , as discussed in table 2 . The figures presented in the study are in 3 parameters. Namely, the fluctuation between the time spent during the rapid response team activation process and the state that the problem ended was to see how long it took field officers to be present after the activation.

Furthermore, the severity level shows the level of austerity experienced by the occurrence based on the assessment from the victim's call to the officer before conducting the field intervention. It Supports officers' readiness to solve problems starting from equipment preparation toward procedures that will be executed in the field. Finally, regarding the PEWS Scoring System, a scoring system is carried out when the officer arrives in the field. PEWS Score is used to evaluate personal victims based on the conditions set out in table 4.

It is not enough that adequate services are carried out by evaluating and familiarity with the task. Nevertheless, additional training needs to be done to achieve an existing service standard. The Asian region has the lowest handling time than the European region [17]. The Asian region has an average of 7.20 minutes to deal with a life-threatening event. Given that the rapid response unit formation at the University of Indonesia campus was only inaugurated in 2016, this unit wants to achieve existing service standards.

The standard to be achieved by the rapid response unit team is divided into three 
different criteria. For a single traffic accident, 7.20 minutes must be achieved. According to Cabral et al. [17] multiple traffic accidents, Lam et al. [18] represent 7.25 minutes, and unexpected events are 7 minutes based on the study by Park et al. [19]For achieving the proven standard, it is necessary to improve the existing system through continuous training in the form of training on enrichment and periodic refresher skills within the current standard time. This achievement can be seen in Figure 2 for a standard single traffic accident achieved in Q2, and in Q3, the average time has reached 6 minutes.

Multiple traffic accidents, the standard was reached at an average of 5.85 minutes in Q2, and unpredictable illnesses occurred in Q2 with an average time of 5.71 minutes and decreased in Q3 by an average of 6.14 minutes. Therefore, based on table 2, periodic training reveals an increase in service quality based on periodic training. Table 5 compares service quality in the response speed for rapid response unit officers with response standards for officers in several Asian countries.

Table 5. Response time comparison

\begin{tabular}{ccc}
\hline Other Reference & Region & Response time (minutes) \\
\hline Kuo, et al. [20] & Taoyuan & 5,00 \\
Lam, et al. [18] & Singapore & 7,25 \\
Park, et al. [19] & Seoul & 7,00 \\
Gholipour, et al. [21] & Tabriz & 17,87 \\
Funada, et al. [22] & Japan (All region) & 7,50 \\
This research before training & Depok, Indonesia & 9,00 \\
This research after training & Depok, Indonesia & 5,40
\end{tabular}

\section{CONCLUSION}

Based on the results and analysis above, it can be concluded that three primary factors influence the crucial level of the incident. Viz, the reporting of the severity level by the victim to activate the rapid response unit and the assessment of the field officer's PEWS so that it affects the mitigation time carried out by the rapid response officer in dealing with the incident. Where the higher the severity level and the PEWS assessment, the longer the mitigation time. The unit's mastery causes the time spent by field officers in handling the task. During five years, the unit operation reduced mitigation time from activating the unit to solving problems. The advancement is due to each incident's evaluation process and the number of incidents that affect rapid response unit officers' experience in solving the field's problems through repetition. Improved service quality is due to continuous training in the form of skill enrichment periodically. The development is done to achieve time standards for three categories of events in the Asian region.

\section{Acknowledgment}

Gratitude to the Government of the Republic of Indonesia, the Ministry of Research and Technology, the National Research and Innovation Agency (Kemenristek BRIN) regarding the Ministry of Research, Technology and Higher Education (Kemenristek Dikti) for funding research for novice lecturers through the announcement of acceptance of research funding and community service, LLDIKTI IV letter no. B / 87 / E3 / RA.00 / 2020 dated January 28, 2020.

The authors would like to give thanks to Herdana Rizky, Assistant of the Rapid Response Unit of the University of Indonesia, who assisted swiftly and carefully in collecting operational data on the fast reaction unit's daily activities in the forest 
environmentally campus at southern hemisphere of the capital city of Jakarta, Indonesia. Next, recognition was given to Sugeng Riyanto and Pupung Purnamasari for their active role in preparing research proposals for novice lecturers and data processing for the initial research activities.

\section{References}

1. Jones DA, DeVita MA, Bellomo R. Rapid response teams. N Engl J Med. 2011;365 (2):139-146.

2. Zenker P, Schlesinger A, Hauck M, et al. Implementation and impact of a rapid response team in a children's hospital. Jt Comm J Qual Patient Saf. 2007;33(7):418-425

3. Kotsakis A, Lobos AT, Parshuram C, et al; Ontario Pediatric Critical Care Response Team Collaborative. Implementation of a multi center rapid response system in pediatric academic hospitals is effective. Pediatrics. 2011;128(1):72 78

4. Maharaj R, Raffaele I, Wendon J (2015) Rapid response systems: a systematic review and meta-analysis. Crit Care 19:254

5. Hillman K, DeVita M, Bellomo R, Chen J (2010) Meta-analysis for rapid response teams. Arch Intern Med 170(11):996-997

6. Chen J, Ou L, Hillman KM, Flabouris A, Bellomo R, Hollis SJ, Assareh H (2014) Cardiopulmonary arrest and mortality trends, and their association with rapid response system expansion. Med J Aust 201(3):167-170

7. Jones D, Moran J, Winters B, Welch J (2013) The rapid response system and end-of-life care. Curr Opin Crit Care 19(6):616-623

8. Bristow PJ, Hillman KM, Chey T, Daffurn K, Jaques TC, Norman SL, et al. Rates of in-hospital arrests, deaths and intensive care admissions: the effect of a medical emergency team. Med J Aust 2000;173:236-40.

9. Parmar A, Richardson H, McKinlay D, Gibney RN, Bagshaw SM. Medical emergency team involvement in patients hospitalized with acute myeloid leukemia. Leuk Lymphoma. 2013;54(10):2236-42.

10. Cole, G.A. 2002. Personnel and human resource management, 5th Ed. Continuum London: York Publishers.

11. Brilli RJ , Gibson R , Luria JW , et al . Implementation of a medical emergency team in a large pediatric teaching hospital prevents respiratory and cardiopulmonary arrests outside the intensive care unit. Pediatr Crit Care Med.2007 ; 8 ( 3 ): 236 - 246, quiz 247

12. Hollnagel, E.: RAG-the resilience analysis grid. In: Hollnagel, E., Paries, J., Woods, D.D., Wreathall, J. (eds.) Resilience Engineering in Practice: A Guidebook, pp. 275-296. Ashgate Publishing Limited, Farnham (2011)

13. Hollnagel, E.: The four cornerstones of resilience engineering. In: Nemeth, C., Hollnagel, E., Dekker, S. (eds.) Resilience Engineering Perspectives: Preparation and Restoration, vol. 2, pp. 117-133. Ashgate, Burlington (2009)

14. Tucker KM, Brewer TL, Baker RB, Demeritt B, Vossmeyer MT. Prospective 
evaluation of a pediatric inpatient early warning scoring system. J Spec Pediatr Nurs. 2009;14(2): 79-85

15. Gheorge V. A., Monnier N.M. (1995). Integrated Regional Risk Assessment: Consequence Assessment of Accidental Releases. ETH Zurich. Switzerland. Vol.II.

16. International first aid and resuscitation guidelines 2016. 1303500 05/2016 E , Geneva

17. Cabral, Eric Lucas dos Santos, Castro, Wilkson Ricardo Silva, Florentino, Davidson Rogério de Medeiros, Viana, Danylo de Araújo, Costa Junior, João Florêncio da, Souza, Ricardo Pires de, Rêgo, Amália Cinthia Meneses, Araújo-Filho, Irami, \& Medeiros, Aldo Cunha. (2018). Response time in the emergency services. Systematic review. Acta Cirurgica Brasileira, 33(12), 1110-1121.

18. Lam SS, Nguyen FN, Ng YY, Lee VP, Wong TH, Fook-Chong SM, Ong ME. Factors affecting the ambulance response times of trauma incidents in Singapore. Accid Anal Prev. 2015.

19. Park GJ, Song KJ, Shin SD, Lee KW, Ahn KO, Lee EJ, Hong KJ, Ro YS. Timely bystander CPR improves outcomes despite longer EMS times. Am J Emerg Med. 2017 Aug;35(8):1049-55.

20. Kuo CW, See LC, Tu HT, Chen JC. Adult outof- hospital cardiac arrest based on chain of survival in Taoyuan County, northern Taiwan. J Emerg Med. 2014 Jun;46(6):782-90.

21. Gholipour C, Shams Vahdati S, Notash M, Miri SH, Ghafouri RR. Success rate of pre-hospital emergency medical service personnel in implementing pre-hospital trauma life support guidelines on traffic accident victims. Turkiye Acil Tip Derg.2014.

22. Funada A, Goto Y, Maeda T, Teramoto R, Hayashi K, Yamagishi M. Improved survival with favorable neurological outcome in elderly individuals with out-of-hospital cardiac arrest in Japan - A nationwide observational cohort study. Circ J. 2016 April 25;80(5):1153-62 